\title{
Forskningsbaseret læring og innovativ praksis på jurauddannelsen
}

Werner Schäfke, ph.d., adjunkt, Det Juridiske Fakultet, Københavns Universitet

Bente Kristiansen, ph.d., læringskonsulent, Det Juridiske Fakultet, Københavns Universitet

Karina Kim Egholm Elgaard, ph.d., adjunkt og postdoc, Det Juridiske Fakultet, Københavns Universitet

Maiken Stensgaard Hølmkjær, cand.jur., Det Juridiske Fakultet, Københavns Universitet

Faglig artikel, fagfællebedømt

På Det Juridiske Fakultet, Københavns Universitet, udvikles en ny læringsplatform i form af et e-tidsskrift inden for skatte- og afgiftsret, UCPH Fiscal Relations Law Journal, med et tilhørende kursus. Her skal de studerende skrive videnskabelige og innovative artikler under tæt supervision af en forsker fra universitetet eller en praktiker fra det offentlige eller private erhvervsliv. Læringsplatformen skal hjælpe de studerende til bedre muligheder for at kombinere retsvidenskabelig forskning med juridisk praksis $i$ en sammenhæng, hvor der lægges vægt på innovation og bredere forståelse af samfundsmæssige problemstillinger. Denne artikel præsenterer, hvordan e-tidsskriftet og det tilhørende kursus påtænkes at arbejde med problemorienteret og forskningsbaseret læring inden for en professionsorienteret universitetsuddannelse. Kurset afholdes for første gang i efterårssemestret 2017. Artiklen præsenterer derfor alene kursusdesignet og de pædagogiske overvejelser bag det, idet vi endnu har evalueringerne til gode, der vil vise, om forventningerne til læringsplatformen kan indfries, når kurset er blevet gennemført.

\section{En brændende platform}

Forskningsbaseret undervisning står højt på agendaen i universitetspædagogisk udvikling i mange fag. På den juridiske uddannelse kan denne tilgang adressere nogle af de udfordringer, som jurister i stigende grad oplever på arbejdsmarkedet. Jurister kommer i højere og højere grad i konkurrence med kandidater fra statskundskab, økonomi og erhvervsjura. Professionssociologiske unders $\varnothing$ gelser har konkluderet, at der er vedvarende forandringer inden for det juridiske arbejdsmarked. Juristerne er under pres fra andre professioner, såvel i den private sektor (Hammerslev, 2010, s. 163, 2011, s. 48) som i den offentlige (Madsen, 2008). Særligt oplever juristerne at blive presset ud af brancher som videnservice, finans og organisation af erhvervsjurister, dvs. cand.merc.jur.'er (Det Juridiske Fakultets Aftagerpanel, 2013).

Disse forandringer stiller krav til jurauddannelsen, som er den eneste uddannelse, der leverer dimittender til den juridiske profession, hvis man ser bort fra andre uddannelser som cand.merc.jur.- og cand.soc.-i-jura-uddannelserne. Disse uddannelser er i tæt konkurrence med jurauddannelsen, hvorfor arbejdsmarkedet er blevet smallere for jurister, dvs. cand.jur.'er. De nye udfordringer for jurauddannelsen er påpeget af aftagere.

Aftagerpanelet ved Det Juridiske Fakultet, Københavns Universitet, udtrykker således ønske om dimittender med et højt fagligt niveau, bedre innovationskompetencer, herunder tværfaglighed samt større forståelse for, hvordan juraen bruges til løsning af komplekse samfundsproblemer 
fra "det virkelige liv" (Det Juridiske Fakultets Aftagerpanel, 2013; jf. Det Juridiske Fakultets Aftagerpanel, 2016b; 2017):

Det er vigtigt, at der oven på den høje kernefaglighed kan bygges en tværgående og tværfaglig overbygning, som kan give jurastudiet e[t] bedre og mere bredt udsyn $i$ forhold til at bidrage til at løse komplekse problemer. Der bør fokuseres på tværfaglighed, der er ikke mange stillinger på arbejdsmarkedet, hvor man kan nøjes med kun at anvende sin jurafaglighed (Det Juridiske Fakultets Aftagerpanel, 2016b).

Vi skal erkende, at der ikke i tilstrækkeligt omfang er en kultur, der understøtter innovation i uddannelsen og udvikle mere innovativt studiemiljø (Det Juridiske Fakultets Aftagerpanel, 2017).

Aftagerpanelet giver også udtryk for deres visioner for fremtidens dimittender. Dimittenderne skal være i stand til at tænke i helheder ud over enkeltfaglige grænser (Det Juridiske Fakultets Aftagerpanel, 2013; 2015, 2016a, 2016b), og uddannelsen skal "øge juristers kreative og løsningsfokuserede mind-set" (Det Juridiske Fakultets Aftagerpanel, 2013; jf. 2014, 2016a, 2016b). Samlet set udtrykker Aftagerpanelet det ideal, som den amerikanske jurist og filosof Lon Fuller formulerede i 1950: "[w]hatever it is we want the student to get, it is something more durable, more versatile and muscular, than a mere knowledge of rules of law" (Fuller, 1950, s. 36).

\section{Læringsplatformen}

Det er disse udfordringer og ønsker, vi gerne vil adressere med e-tidsskriftet og det tilknyttede kursus "Innovation og entreprenørskab inden for skatte- og afgiftsret". ${ }^{1}$ Med henblik på at arbejde med mere tværfaglig og innovativ tænkning har vi forsøgt at tilrettelægge en proces med problemorienteret, forskningsbaseret læring. Ved at knytte et tidsskrift og et kursusfag tæt sammen håber vi på at invitere de studerende til at deltage i et fagligt og professionelt fællesskab. De kan aflevere deres projekt alene som en eksamensopgave, men de kan også arbejde med projektet som et bidrag til tidsskriftet og dermed arbejde videre med de faglige og professionelle kriterier, som er en del af det skatte- og afgiftsretlige fagfællesskab. Tidsskriftet og kurset har en stærk forskningsmæssig forankring i en forskningsgruppe for skatte- og afgiftsret ${ }^{2}$ og har samtidig en stærk forankring i det praktiske liv gennem undervisere, case-virksomheder og redaktionsmedlemmer, der arbejder i praksis med skatte- og afgiftsretlige problemstillinger. Vi ser mange muligheder for innovation i krydsfeltet mellem forskning og praksis, og det er netop her, at vi vil invitere de studerende ind på en ny læringsplatform, der både er curriculær og ekstracurriculær.

Som nævnt er den nye læringsplatform organisatorisk forankret i forskningsgruppen FIRE - Fiscal Relations Research Group, der bl.a. har til formål at virke som aktivt bindeled mellem studerende, forskere og praktikere med henblik på at styrke det skatte- og afgiftsretlige forsknings- og uddannelsesmiljø. Udviklingen af læringsplatformen er sket i meget tæt samarbejde med Forsk-

\footnotetext{
${ }^{1}$ Fonden for Entreprenørskab har medfinansieret vores projekt "Opnåelse af entreprenørskabskompetencer gennem nyt og innovativt e-tidsskrift", http://jura.ku.dk/fire/nyheder/ucph-lawjournal-for-fiscal-relations/.

${ }^{2}$ FIRE - Fiscal Relations Research Group, Det Juridiske Fakultet, Københavns Universitet, www.jura.ku.dk/fire.
} 
ningsgruppen for retsvidenskabelig didaktik ${ }^{3}$ for at sikre en universitetspædagogisk funderet implementering af kurset. Der står således et fast sammentømret forskningsmæssigt hold bag den nye læringsplatform både fra den faglige og fra den universitetspædagogiske side. Dette samarbejde er væsentligt for at sikre høj faglig kvalitet, tiltrække eksterne samarbejdsparter samt gøre e-tidsskriftet attraktivt for en klart afgrænset målgruppe af skatte- og afgiftseksperter.

Det er vigtigt for den nye læringsplatform, at forskningsbaseret læring kombineres med praktisk anvendelse af juraen, hvilket $\mathrm{i}$ høj grad sker ved inddragelse af eksterne samarbejdsparter fra erhvervslivet $\mathrm{i}$ alle sammenhænge $\mathrm{i}$ forbindelse med læringsplatformen. Eksterne samarbejdsparter har holdt oplæg på informationsarrangementer, deltager i redaktionen, underviser på kurset, agerer som case-virksomhed eller bedømmer de studerendes præsentationer på kurset. De eksterne samarbejdsparter er alle skatte- og afgiftseksperter, men fra forskellige brancher såsom et forlag, en tænketank, advokat- og rådgivningsvirksomheder samt offentlige virksomheder. Læringsplatformen giver de studerende gode muligheder for at udtænke innovative løsninger, der både er forskningsbaserede og implementerbare i praksis, hvilket er en efterspurgt kompetence i den juridiske profession.

Da vores artikel indeholder en præsentation af kursusdesignet samt vores pædagogiske overvejelser bag dette, er der tale om vores forventninger og kvalificerede antagelser til kurset og tidsskriftet som ny læringsplatform, idet det kommer an på den faktiske gennemførelse heraf, hvorvidt vores forventninger kan indfries eller ej.

\section{E-tidsskriftet}

Vores nyudviklede læringsplatform består af to dele: e-tidsskriftet og et tilhørende kursus. Etidsskriftet hedder UCPH Fiscal Relations Law Journal ${ }^{4}$ og skal udgives som et Open Accessonlinetidsskrift af et forlag. Det skal tage imod artikler på dansk, norsk, svensk og engelsk. De overordnede faglige krav er, at artiklerne er videnskabelige, innovative og i et eller andet omfang vedrører en skatte- eller afgiftsretlig problemstilling. Tidsskriftet vil være åbent for forfattere fra alle fagområder og discipliner og for studerende såvel som forskere og praktikere.

E-tidsskriftet fungerer som et almindeligt tidsskrift, hvor redaktionen består af studerende, forskere fra forskellige institutioner samt praktikere fra det offentlige og private erhvervsliv. I skrivende stund er der 14 redaktionsmedlemmer, heraf tre studerende, to nyuddannede, syv forskere og fire praktikere. Redaktionen administrerer tidsskriftet og godkender indkomne artikler til fagfællebedømmelse. Fagfællebed ømmelsen er double blind og foretages som udgangspunkt af en studerende i samarbejde med en forsker eller praktiker, medmindre artiklen sendes til ekstern fagfællebedømmelse. Under hele udviklingen af læringsplatformen har vi haft stort fokus på studenterinvolvering, tæt samarbejde mellem studerende, forskere og praktikere samt læring gennem feedback, hvorfor det er naturligt at invitere de studerende til at lære mere ved at deltage i en superviseret fagfællebedømmelse. Den endelige artikel godkendes af en forsker fra redaktionen $f ø r$ publicering.

Redaktionen fungerer som kontaktdatabase, hvor studerende (ekstra-curriculært) kan tilmelde sig, hvis de $\varnothing$ nsker at skrive en artikel under supervision af eller i samarbejde med en forsker

\footnotetext{
${ }^{3}$ www.jura.ku.dk/lawteaching.

${ }^{4} \mathrm{http}$ :/jura.ku.dk/firejournal/.
} 
eller praktiker. Studerende kan også tilmelde sig, hvis de selv skriver en artikel, der eksempelvis er baseret på et bachelorprojekt eller kandidatspeciale. På samme måde inviteres forskere og praktikere til at tilmelde sig kontaktdatabasen. Tanken bag kontaktdatabasen er altså den samme som bag kurset, hvilket er at kombinere forskning, praksis og innovation ved at bringe studerende sammen med forskere og eksterne samarbejdsparter. Dette er ment til at styrke sammenhængen mellem curriculære og ekstra-curriculære aktiviteter på en god måde, der giver mening for alle parter.

De studerendes artikler, som publiceres i e-tidsskriftet, vil kunne indgå direkte i undervisningen på skatte- og afgiftsfagene. På kurset "Innovation og entreprenørskab inden for skatte- og afgiftsret" kan studerende, der indgår i nye kursusforløb, med fordel anvende tidligere artikler som videndatabase. Artiklerne kan også bruges af skatte- og afgiftseksperter, der vil vide mere om det pågældende område.

\section{Kurset}

Det til e-tidsskriftet tilknyttede kursus hedder "Innovation og entreprenørskab inden for skatteog afgiftsret" og er på 15 ECTS. Kurset udbydes som et valgfag på kandidatuddannelsen fra og med efteråret 2017. ${ }^{5}$ Kurset indeholder forskellige elementer vedrørende innovation, akademisk skrivning, projektarbejde, Real-Life-Cases m.v. De studerende arbejder selvstændigt med en selvvalgt problemformulering, individuelt pensum, projektstyring, skrivning og refleksion. Fra start til slut får de studerende løbende planlagt feedback fra undervisere, medstuderende og eksterne samarbejdsparter, hvilket kan ske en-til-en, i grupper eller i plenum.

Til eksamen afleverer de studerende en videnskabelig og innovativ artikel på 15-25 sider og en afsluttende skriftlig refleksion (maks. 30 normalsider i alt). Refleksionen går ud på, at den studerende med baggrund $\mathrm{i}$ en læringslogbog reflekterer over sin egen læreproces: Hvordan håndterer jeg faglige udfordringer, hvordan arbejder jeg innovativt, hvordan giver og modtager jeg feedback etc.

Kurset er tilknyttet e-tidsskriftet på den måde, at når den studerende har arbejdet i dybden med læringsmålene for kurset, vil den studerende ideelt set have skrevet en artikel af en sådan kvalitet, at den kan indsendes til e-tidsskriftet og publiceres efter fagfællebedømmelse. Vurderingsog bedømmelseskriterierne inden for kurset hænger derfor tæt sammen med kvalitetskriterierne for publicering i e-tidsskriftet, hvorved der gerne skulle skabes en direkte sammenhæng mellem det curriculære og det ekstra-curriculære læringsudbytte. Udover at e-tidsskriftet er en integreret del af læringsplatformen, er der tale om et tværvidenskabeligt forskningstidsskrift, hvor det er hensigten, at det også skal blive et fagligt tidsskrift med indflydelse på praksis på skatte- og afgiftsområdet. Det er denne kobling mellem forskning, læring og praksis, vi ser pædagogiske potentialer $i$, og som vi håber vil blive dokumenteret gennem evalueringerne af kurset senere hen.

\section{Læringsstrategi}

Vi arbejder med, hvad der betegnes som problemorienteret projektarbejde i universitetsundervisning:

\footnotetext{
${ }^{5}$ http://kurser.ku.dk/course/jjua55187u/2017-2018.
} 
[...] en deltagerstyret studieform, hvor man arbejder med at formulere, begrunde og metodisk undersøge en saglig problemstilling - noget, man ikke ved - ved hjælp af videnskabelige metoder og teorier - ofte tværvidenskabeligt og ofte i grupper. Der udarbejdes et produkt - typisk en projektrapport (Pedersen, 2015, 15, originale fremhævelser).

I vores tilfælde er produktet en akademisk artikel til et konkret fagligt relevant tidsskrift samt en skriftlig refleksion over arbejdsprocessen og dens styring. Hvor de færreste studerende vil opleve, at deres projektrapporter drøftes uden for universitetssammenhænge, kommer disse studerende gennem deres arbejde med artiklen til i bedste fald at deltage $i$ et eksisterende fagligt diskursfællesskab inden for skatte- og afgiftsret. Dels fordi de skal arbejde og skrive ud fra de samme kriterier som andre professionelle skribenter til tidsskriftet, dels fordi undervisningen er organiseret sådan, at de får feedback fra diskursfællesskabet, nemlig forskere og praktikere inden for skatte- og afgiftsret.

Tilgangen, arbejdsmetoden og resultatet er således forskningsbaseret, idet de studerende skal lære at arbejde som en forsker (Healey \& Jenkins, 2009, s. 8). De studerende skal finde en ny problemstilling, som de skal forske i, behandle og analysere, og derefter aflevere deres forskningsresultat i form af en artikel, der formidler deres forskning. For at kunne leve op til et rimeligt videnskabeligt niveau er det nødvendigt at sætte sig ind i state-of-the-art på området, dvs. nationale og internationale forskningsartikler, ph.d.-afhandlinger m.v. Arbejdet med artiklen skal åbne de studerende op for problemløsende tænkning, som går ud over deres traditionelle juridiske faglighed, og de studerende skal optimalt set lære, hvordan en forskende metode kan bidrage til at løse komplekse samfunds- og erhvervsmæssige problemer og ikke kun er et redskab til at kunne skrive et afsluttende speciale.

Derved bryder dette forløb med den case-baserede undervisning, som traditionelt dominerer $\mathrm{i}$ juridiske uddannelser (Krogh, Stentoft, Emmersen, \& Mausaeus, 2013, s. 201-202; Wilhelmsen, 2014c, s. 166-167). Cases i juridiske uddannelser handler ofte om domme, som enten er blevet ankede, eller som kunne ankes (Wilhelmsen, 2014c, s. 166-167). Rammen for at undersøge et problem i en case ligger typisk inden for den juridiske fagdisciplin med anvendelse af juridisk metode og juridisk argumentation. I Norge gav Bolognaprocessen og arbejdet med den norske kvalifikationsramme anledning til et større didaktisk arbejde med udvikling af de juridiske uddannelser, hvor man gik i retning af problembaseret læring (Wilhelmsen, 2014a, s. 5).

I sammenhæng med problembaseret læring på juridiske uddannelser kan der skelnes mellem problemer på tre forskellige niveauer, der er relateret til Blooms taksonomi (Wilhelmsen, 2014c, s. 159): Niveau 1 er opgaver, der handler om fakta, forståelse og anvendelse af relevante retsregler. Den viden, den studerende har brug for til at kunne løse problemet, findes i pensum. Niveau 2 er velstrukturerede problemer. Her går man lidt højere op i Blooms taksonomi og udvikler færdigheder såsom analyse, syntese og strukturering. Ikke alle nødvendige informationer til at besvare problemet findes i pensummet, men stadig inden for det stof, de studerende er blevet præsenteret for i den organiserede undervisning. Niveau 3 er ufuldstændigt strukturerede problemer, hvor de studerende vil være $n \varnothing \mathrm{dt}$ til selv at finde alternative informationskilder ud over det, som de er blevet præsenteret for i den organiserede undervisning. De mest velegnede problemer på dette niveau er Real-Life-Cases: "Den beste form for ufullstendig strukturerte problemoppgaver er virkeligheten selv" (Wilhelmsen, 2014c, s. 159). Det er denne type problemer, 
de studerende på vores kursus kommer til at arbejde med, hvilket forhåbentlig sker med inddragelse af tværfaglige problemstillinger og innovativ tænkning.

Ved at sætte en akademisk artikel som mål for de studerendes arbejde håber vi, at det bliver meget tydeligt for de studerende, hvordan forskningens metodikker kan bidrage til at kvalificere besvarelser af problemstillinger. Det er også vores håb og formodning, at de studerendes arbejde på kurset viser sig at give væsentlige bidrag til innovativ tænkning på det skatte- og afgiftsretlige område, hvilket vil gavne samfundet i flere henseender. At det med artikelformen handler om en faktisk tekstgenre, forbereder de studerende bedst muligt på faglig skriftlighed (Carter, 2007, s. 410; Tynjälä, 1998).

Kursets tilgang til at lade de studerende tage udgangspunkt i problemstillinger fra praksis i samarbejde med aktører uden for universitetet realiserer en af de mest åbne og samfundsorienterede tilgange til tværfaglighed: transdisciplinaritet. Transdisciplinær forskning betegner forskning som fokuserer på løsningen af komplekse samfundsproblemer, som rækker ud over én etableret disciplins grænser (Klein, 2010, s. 24-25; Mittelstrass, 2011, s. 331). For de studerende betyder det at lære, at man aktivt bringer sin faglighed i samspil med andre fagligheder for at udvikle innovative løsninger på faktiske, komplekse problemer. Denne arbejdsform underst $\emptyset$ tter også åbenhed, selvstændighed og mod til at tåle uklarheder og modsigelser i forskellige disciplinære opfattelser og forudsætninger (Armstrong, 1988).

\section{Undervisningsformater}

Overordnet arbejder vi med to undervisningsformater, innovationsseminarer og skriveværksteder, der begge foregår under Innovation Hubs. Innovation Hub er et andet navn for den skemalagte undervisning, idet vi har samlet alle ugens timer på den samme dag. I forbindelse med innovationsseminarer gennemfører de studerende forskellige innovations- og design-thinking$\varnothing$ velser. Her kombineres juridisk viden med praktiske problemer, idet eksterne samarbejdsparter deltager som case-virksomheder eller diskuterer og bedømmer de studerendes præsentation af løsninger. Skriveværkstederne er ledet af en facilitator. Hvert værksted indledes med, at de studerende gennemfører en tjek-ind, hvor de formulerer deres aktuelle udfordringer.

Derudover har de studerende på forskellige tidspunkter i kursusforløbet en række peerfeedbackaktiviteter, der skal hjælpe dem videre med skriveprocessen. Sådanne peerfeedback-aktiviteter er bl.a. rundbordsseminarer og mundtlig opfølgning på skriftlig peerfeedback på midtvejsudkast af deres artikel. ${ }^{6}$ Herudover får de studerende individuel mundtlig og skriftlig vejledning fra en forsker eller praktiker, som er ekspert i projektets område, hvilket yderligere hjælper de studerende videre med skrivningen.

Undervisningsformaterne afspejler vigtige aktiviteter i både forskningsarbejde og juridisk praksis. Rundbordsseminarer svarer til lignende seminarer for ph.d.-studerende og til andre mundtlige oplæg, som f.eks. konferenceoplæg. Skriftlig peerfeedback svarer til fagfællebedømmelse på tidsskriftsartikler og kollegers artikeludkast. Den arbejdsform genkendes også i praktikernes arbejde, idet rundbordsseminarer kan sammenlignes med at afrapportere over for en bestyrelse

\footnotetext{
${ }^{6}$ Feedback-vejledninger hertil er tilgængelige på www.jura.ku.dk/firejournal/kursus/undervisningsplan/ som bilag til Undervisningsplanen af 7. august 2017 udarbejdet af Karina Kim Egholm Elgaard, Werner Schäfke og Bente Kristiansen.
} 
eller afholde en salgstale over for en ny kunde. I rådgivningsfirmaer vil der ofte være regler om intern fagfællebedømmelse af en eller to seniorer af ethvert skriftligt arbejde, der sendes ud af huset, ligesom ens arbejde normalt skal ændres og godkendes efter chefens kommentarer. Her er der dog en klar forskel i forhold til kurset, idet de studerende selv træffer beslutninger på baggrund af feedback. Endelig er det typisk både for forskere og praktikere, at det er nødvendigt at arbejde tæt sammen med andre faggrupper end ens egen for at kunne løse opgaverne.

\section{Innovation Hub}

For at skabe en fast ramme og et innovationsmiljø omkring de forskellige læringsaktiviteter og interaktioner mellem de studerende, undervisere og eksterne samarbejdsparter på kurset er holdundervisningen i stedet for at være spredt samlet til én ugentlig Innovation Hub på fire til fem timers længde. På Innovation Hubs fungerer underviseren som facilitator, der styrer dagens aktiviteter og motiverer fremdriften af de studerendes projekter. Det er vigtigt, at facilitatoren er proaktiv og engageret $i$, hvordan det går de studerende her og nu, og hvad de har brug for fremadrettet. Når der ikke er flere planlagte aktiviteter, som f.eks. rundbordsseminar og gruppepeerfeedback, overgår Innovation Hub til at være et skriveværksted, hvor de studerende skriver og diskuterer med hinanden under tilstedeværelse af facilitatoren.

Det at kunne tale om og dele sin skriveproces med andre skrivende har stor betydning for fremdrift i skriveprocesser, fordi det at tale om sin skrivning er med til at udvikle bevidsthed om både genrekrav og skrivestrategier (Murray, 2012). Ligeledes må man forvente, at innovative processer får mere næring og fremdrift i et åbent og trygt fagligt miljø. Skriveværkstederne giver mulighed for hurtig og direkte dialog samt eventuelt afklarende spørgsmål til den tilstedeværende facilitator.

\section{Rubrikker}

Med henblik på at understøtte en fælles forståelse af de pædagogiske mål og den pædagogiske indsats, og ikke mindst betydningen af konstruktiv feedback både under rundbordsseminarer og skriftlig peerfeedback, afholdes der en workshop for underviserne kort før kursusstart. Her tales der om moderation af feedbacksituationer, og hvordan man som facilitator kan skabe holdstemning på kurset, så de studerende ser sig som et fælles team, der ikke er i indbyrdes konkurrence, men derimod st $\varnothing$ tter og hjælper hinanden. Underviserne har en detaljeret undervisningsplan med et omfattende bilagsmateriale at støtte sig til. ${ }^{7}$ Til underst $\varnothing t t e l s e$ af læringsprocesserne er der vejledninger til såvel mundtlige som skriftlige feedbackformer og vejledning til arbejdet med en refleksionslog.

Vi ved fra KU's studiemiljøundersøgelse og de studerendes evalueringer af specialeskrivning, at de er usikre på de faglige forventninger på jurauddannelsen (Københavns Universitet, 2016). Derfor har vi udførligt beskrevet kursets læringsmål og kvalitetskriterier for eksamenen i form af rubrikker, og vi har kommenteret på en videnskabelig artikel inden for det afgiftsretlige område, hvordan de enkelte tekstafsnit indfrier specifikke kriterier for akademisk skrivning og innovation på området. ${ }^{8}$

7 Undervisningsplan med bilag af 7. august 2017 er tilgængelig på www.jura.ku.dk/firejournal/kursus/undervisningsplan/.

${ }^{8}$ Fremgår af bilag 5 til Undervisningsplanen, der er tilgængelig i det digitale kursusrum. 
Rubrikkerne beskriver de kriterier, der lægges til grund for vurderingen af eksamensbesvarelsen, og operationaliserer disse kriterier i forhold til eksamensproduktet (jf. Andrade, 2005; Andrade \& Reddy, 2010; Andrade \& Warner, 2012). Eksamensproduktet består af den videnskabelige artikel, de studerende skriver, samt en afsluttende skriftlig refleksion over deres læringsproces. ${ }^{9}$ Bedømmelseskriterierne for refleksionsloggen bygger på rubrikkerne for læringsmål udviklet i projektet "Innovation og entreprenørskab" på Københavns Universitet (Københavns Universitet, 2013), som bl.a. vedrører styring af projektarbejdet, beslutningskompetence, eksperimentering, værdiskabelse og feedback (se Tabel 1). ${ }^{10}$

Rubrikkerne med kvalitetskriterier for artiklen handler bl.a. om begrebsanvendelse, analyse, juridisk argumentation og kritisk refleksion (se Tabel 2). ${ }^{11}$ Rubrikkerne er et fors $\varnothing \mathrm{g}$ på at gøre det mere klart og synligt både for de studerende og for underviserne, hvilke faglige forventninger der er til dem. Selvom rubrikkerne ikke kan afklare enhver usikkerhed omkring kursets faglige kriterier, giver de et konkret grundlag at tale ud fra.

\begin{tabular}{|l|l|l|}
\hline Rubrik & Karakter & Bemærkninger \\
\hline $\begin{array}{l}\text { Inddrage tværfaglige perspektiver i arbejdet med } \\
\text { problemstillingen }\end{array}$ & & \\
\hline $\begin{array}{l}\text { Kortlægge og kritisk vurdere eksisterende løsnin- } \\
\text { ger, teknologier og praksisser }\end{array}$ & & \\
\hline $\begin{array}{l}\text { Undersøge og (re-)definere en problemstilling i } \\
\text { samspil med relevante aktører og under inddra- } \\
\text { gelse af forskellige perspektiver }\end{array}$ & & \\
\hline $\begin{array}{l}\text { Anvende metoder til at udvikle innovative (kreati- } \\
\text { ve) løsninger i relation til et givent fagområde }\end{array}$ & & \\
\hline $\begin{array}{l}\text { Prioritere og strukturere undersøgelsen selvstæn- } \\
\text { digt }\end{array}$ & & \\
\hline $\begin{array}{l}\text { Anvende og analysere forskellige procesmodeller } \\
\text { og tilgange til innovation og entreprenørskab }\end{array}$ & & \\
\hline $\begin{array}{l}\text { Indsamle, vurdere og inkorporere kvalificeret } \\
\text { feedback med henblik på at målrette løsningen til } \\
\text { den konkrete kontekst og relevante interessenter }\end{array}$ & & \\
\hline $\begin{array}{l}\text { Generere, kvalificere og vurdere idéer ud fra rele- } \\
\text { vante kriterier med henblik på en konkret værdi- } \\
\text { skabelse ( } \varnothing \text { konomisk, kulturelt, socialt) i nye og } \\
\text { skiftende kontekster }\end{array}$ & & \\
\hline
\end{tabular}

Tabel 1: Uddrag af bilag 6, pkt. 3, til Undervisningsplan af 7. august 2017.

9 Der er udarbejdet en vejledning til den løbende refleksionslog, jf. bilag 3 til Undervisningsplanen.

${ }^{10}$ Jf. bilag 6 til Undervisningsplanen.

${ }^{11} \mathrm{Jf}$. bilag 6 til Undervisningsplanen. 
Sådan en bevidstgørelsesproces omkring faglige kriterier betragter vi som meget frugtbar for den faglige udvikling af jurauddannelsen. Mange juridiske fag har rettevejledninger til eksamensopgaver, og selvom de ikke kun arbejder med kriterier, der vurderer et svar som rigtigt eller forkert, er disse kriterier ofte lukkede. Rettevejledninger kan have deres berettigelse til vurdering af eksamensspørgsmål, der har karakter af det, Wilhelmsen (2014b, s. 159) betegner som velstrukturerede problemer. Men for at vurdere problemorienteret projektarbejde er man nødt til at arbejde med kriterier, som giver gennemskuelige kriterier for en saglig vurdering.

\begin{tabular}{|c|c|}
\hline Læringsmål & Kriterier \\
\hline $\begin{array}{l}\text { Reflektere over/diskutere skatte- og afgiftsretlige } \\
\text { problemstillinger/aspekter inden for en selvvalgt } \\
\text { problemstilling }\end{array}$ & $\begin{array}{l}\text { - Dette er naturligvis kernen i artiklen } \\
\text { - Er der fundet frem til en egnet problemstil- } \\
\text { ling for en artikel? }\end{array}$ \\
\hline $\begin{array}{l}\text { Reflektere over dansk skatte- og afgiftsret i en } \\
\text { international sammenhæng, såfremt det er rele- } \\
\text { vant for artiklen }\end{array}$ & $\begin{array}{l}\text { - Indeholder artiklen inddragelse af/refleksion } \\
\text { over internationale perspektiver? } \\
\text { - Hvor kvalificerede er disse refleksioner? } \\
\text { - Bidrager det til at sætte problemstillingen i et } \\
\text { internationalt perspektiv? }\end{array}$ \\
\hline $\begin{array}{l}\text { Argumentere på en juridisk holdbar måde inden } \\
\text { for den valgte problemstilling }\end{array}$ & $\begin{array}{l}\text { - Hænger argumentationen logisk sammen og } \\
\text { er den overbevisende? } \\
\text { - Leder argumenterne på en god måde fra } \\
\text { problemstillingen via analysen og frem til resul- } \\
\text { tatet? } \\
\text { - Er argumentationen skarp, fokuseret og præ- } \\
\text { cis? }\end{array}$ \\
\hline $\begin{array}{l}\text { Inddrage tværfaglige perspektiver i arbejdet med } \\
\text { problemstillingen }\end{array}$ & $\begin{array}{l}\text { - Anvendes resultater fra andre juridiske om- } \\
\text { råder eller ikke-juridiske discipliner for bedre at } \\
\text { forstå den valgte problemstilling? } \\
\text { - Anvendes metoder eller teorier fra andre } \\
\text { juridiske områder eller ikke-juridiske discipliner } \\
\text { for at finde innovative løsninger til den valgte } \\
\text { problemstilling? } \\
\text { - Anvendes resultater fra andre juridiske om- } \\
\text { råder eller ikke-juridiske discipliner for at kvalifi- } \\
\text { cere den juridiske argumentation? }\end{array}$ \\
\hline Diskutere egne resultater & $\begin{array}{l}\text { - Hvilke forbehold tages for egne konklusioner, } \\
\text { metoder m.v.? } \\
\text { - Er der kritisk stillingtagen til egne resultater? } \\
\text { - Er der inddraget modstående holdninger? }\end{array}$ \\
\hline $\begin{array}{l}\text { Formidle unders } \emptyset \text { gelsen i en retsvidenskabelig } \\
\text { artikel }\end{array}$ & $\begin{array}{l}\text { - Er formidlingen af stoffet god i artiklen? } \\
\text { - Er artiklen generelt egnet til publikation? }\end{array}$ \\
\hline Give og modtage feedback & $\begin{array}{l}\text { - Er karakteristika for givet og modtaget feed- } \\
\text { back identificeret, der gjorde feedbacken kon- } \\
\text { struktiv og nyttig? }\end{array}$ \\
\hline
\end{tabular}

Tabel 2: Uddrag af bilag 6, pkt. 1, til Undervisningsplan af 7. august 2017. 
Rettevejledninger kan have deres berettigelse til vurdering af eksamensspørgsmål, der har karakter af det, Wilhelmsen (2014b, s. 159) betegner som velstrukturerede problemer. Men for at vurdere problemorienteret projektarbejde er man $n \varnothing d t$ til at arbejde med kriterier, som giver gennemskuelige kriterier for en saglig vurdering af ny viden, nye vinkler og uforudsete besvarelser, dvs. innovativ tænkning. Vi har planlagt en evaluering for at kunne kvalitetsudvikle kriterierne efter afslutningen på den første kursusudrulning.

\section{Feedback}

Vi vægter feedback meget højt af to grunde. Den ene er, at feedback er en væsentlig professionel kompetence - ikke mindst på det juridiske arbejdsmarked. Juridiske tekster skal være præcise, og de rettes og omskrives i stor stil, så tekstfeedback skal man både kunne give og modtage som jurist. Det er ikke naturgivent, at det er en rar proces. Derfor er det en værdifuld kompetence for de studerende at have kendskab til, hvordan man kan give tekstfeedback konstruktivt. Københavns Universitet har inden for de seneste år arbejdet målrettet med at sætte $\emptyset$ get formativ feedback på uddannelserne på agendaen (Jørgensen, Dolin, Hvithamar, Magnusson, \& Holde, 2015), fordi formativ feedback er vigtig for de studerendes læringsudbytte (Nicol \& Macfarlane-Dick, 2006).

Den anden grund handler om faglig læring. Formativ feedback støtter faglig læring (Nicol \& Macfarlane-Dick, 2006), hvorfor Københavns Universitet inden for de seneste år har arbejdet målrettet med at sætte øget formativ feedback på uddannelserne på agendaen (Jørgensen et al., 2015).

En god formativ feedbackproces understøtter læring gennem Feed Up, Feed Back og Feed Forward (Hattie \& Timperley, 2007). Feed-Up-processen bliver støttet af rubrikkerne, hvor underviserne og studerende sikrer en fælles forståelse af læringsmålene. Kurset indeholder derudover aktiviteter, hvor studerende får feedback fra deres medstuderende samt fra undervisere og vejledere på deres konkrete udfordringer og tekster. Når man forholder sig til andres tekster ud fra specifikke faglige kriterier, lærer man kriterierne at kende. Man udvikler både sin tekstforståelse og faglige forståelse ved at påpege, præcis hvor og præcis hvordan faglige kriterier er imødekommet eller mangler i en tekst. Det er derfor langt mere lærerigt at give feedback end at modtage feedback (Nicol, Thomson, \& Breslin, 2013).

Fordi feedback-formerne udgør en så vigtig del af de studerendes læring på kurset, har vi indlagt flere forskellige former for feedback. Feedback-processen er tilrettelagt således, at hver enkelt studerende:

1. præsenterer sin projektidé og projektdesign under et rundbordsseminar,

2. giver feedback til de andre studerendes projektidéer og projektdesigns under deres rundbordsseminarer,

3. modtager skriftlig og mundtlig feedback fra mindst to andre studerende på midtvejsudkastet til sin artikel,

4. giver skriftlig og mundtlig feedback til disse andre studerendes midtvejsudkast til deres artikler,

5. får skriftlig og mundtlig feedback fra sin vejleder på midtvejsudkastet til sin artikel, 
6. får formativ feedback med forbedringsforslag fra eksaminatoren, så en endnu bedre version kan indleveres til e-tidsskriftets redaktion efter kurset.

Rundbordsseminarerne bliver afholdt under Innovation Hubs, hvor en studerende præsenterer sit projekt. Øvrige deltagere på kurset er til stede og giver feedback på baggrund af en feedbackvejledning, ${ }^{12}$ som - sammen med moderationen fra facilitatoren - skal sikre et konstruktivt og trygt miljø.

Den skriftlige peerfeedback på de studerendes midtvejsudkast til deres artikler skal give de studerende indblik i forskellige muligheder for at strukturere en artikel og samtidig skærpe deres blik for klar og faglig sprogbrug. Peerfeedbacken sker på baggrund af en vejledning hertil, ${ }^{13}$ understøttet af de oven nævnte rubrikker. ${ }^{14}$ De studerende skal følge op på den skriftlige feedback med en mundtlig feedback-runde for at sikre forståelsen af feedbacken og for at give feedbackgiverne mulighed for at erfare, hvordan deres feedback forstås og kan bidrage til den videre proces.

Det samme gælder for vejlederens skriftlige feedback på et midtvejsartikeludkast - som ideelt set ikke er det samme midtvejsudkast, som de medstuderende får, da det kan give mere værdi for den studerende at prioritere forskellig feedback fra forskellige personer med forskellige kompetencer. Også her skal vejlederne tage udgangspunkt i kvalitetskriterierne samt følge op på deres skriftlige kommentarer under et personligt vejledningsm $\varnothing$ de for at sikre en god kommunikation.

\section{Studenterpanel}

I forbindelse med udviklingen af kursusdesignet inviterede vi et studenterpanel til at kommentere herpå samt kommentere på udkastet til undervisningsplanen med bilag for at få de studerendes respons på det planlagte nye kursus. Vi var særligt interesserede $\mathrm{i}$, om de rammer, vi udviklede, også kunne skabe social og faglig tryghed hos de studerende, og om feedbackvejledningerne samt kvalitets- og bedømmelseskriterierne var til at forstå for de studerende.

Studenterpanelet bestod af tre jurastuderende på kandidatuddannelsen. De blev præsenteret for undervisningsplanen med bilag, som de studerende får udleveret ved kursusstart. Materialet bestod af kursusbeskrivelsen, undervisningsplanen, feedback-vejledninger, bedømmelsesskemaer i form af "rubrikker" og et eksempel på, hvordan en konkret innovativ juridisk artikel kan se ud. De studerende blev bedt om at læse materialet grundigt og give deres feedback ved panelmødet.

Overordnet var der bred enighed om, at kurset kan give et stort fagligt udbytte. De studerende mente, at kursusfaget ville styrke kursusdeltagernes skriftlige kompetencer og deres faglighed ved at arbejde i dybden med innovative projekter på et højere videnskabeligt niveau. Derudover mente de, at kurset ville give gode muligheder for at forbedre sit $\mathrm{CV}$, fordi man kunne udvikle og dokumentere kompetencer som f.eks. samarbejde, feedback, skriftlighed og innovation.

\footnotetext{
${ }^{12}$ Jf. bilag 2 til Undervisningsplanen.

${ }^{13}$ Jf. bilag 4 til Undervisningsplanen.

${ }^{14}$ Jf. bilag 6 til Undervisningsplanen.
} 
If $\varnothing$ lge vores mødereferat havde de studerende dog en række bekymringer for, hvordan deres medstuderende ville opfatte kurset:

- Det er vigtigt, at kursusbeskrivelsen tiltrækker motiverede studerende, så Innovation Hubatmosfæren efter sit formål faciliterer et kreativt og innovativt arbejdsmiljø.

- Antallet af deltagere bør ikke være større end 15 til at starte med, da den faglige dynamik risikerer at mindskes.

- Det bør være meget tydeligt, at det faglige udbytte er stort.

- Innovation inden for den juridiske disciplin er ret nyt, og det er derfor vigtigt, at innovationsbegrebet bliver uddybet nærmere over for de studerende, f.eks. gennem en række eksempler, en video eller et idékatalog.

- På baggrund af kursusfagets nye og særegne karakter mener studenterpanelet, at det kunne være en fordel, hvis de studerende bl.a. fik en vejledende tidsplan, hvori det illustreres, hvordan processen for et kursusforløb kan se ud.

- Det kan afskrække studerende fra at tage faget, hvis de føler sig utrygge ved undervisningsformen, bl.a. rundbordsseminarer med feedback.

Studenterpanelets kommentarer førte til en række indsatser fra vores side. For at klargøre innovationsbegrebet bedre for de studerende er der opbygget et idékatalog på e-tidsskriftets hjemmeside, ${ }^{15}$ så de studerende kan lade sig inspirere allerede inden, de starter på kurset. Tillige blev der indsat flere eksempler på, hvad der kunne være innovativt $i$ en artikel i kursusbeskrivelsen og i Undervisningsplanen. Undervisningsplanen er suppleret med en vejledende tidsplan, ${ }^{16}$ så de studerende kan få et bedre overblik over hele kursusforløbet til eksempel.

Maksimumdeltagerantallet på kurset blev reduceret til 15 studerende for at sikre tryghed og en god kommunikativ dynamik mellem de studerende. Dette tiltag kan også betragtes som meningsfuldt ud fra et pædagogisk perspektiv, fordi en mindre holdstørrelse på ca. 15 studerende har positive effekter på det sociale klima og læringen (Zyngier, 2014).

For at tiltrække motiverede studerende blev der afholdt et informationsmøde for studerende på Det Juridiske Fakultet, hvor vi præsenterede kursusdesignet og de muligheder, et sådant kursus tilbyder for at arbejde uden for de kendte rammer for læring på fakultetet. Derudover var der oplæg fra dekanen, Fonden for Entreprenørskab, forlaget, tre advokat- og rådgivningsvirksomheder samt en tænketank. De understregede alle, hvordan kursets læringsmål og design potentielt giver muligheder for et stort fagligt udbytte, og gav eksempler på, hvordan virksomhederne efterspørger innovations- og entreprenørskabskompetencer hos nyuddannede.

\section{Konklusion}

Formålet med udviklingen af vores kursusdesign for den nye læringsplatform med e-tidsskriftet er at adressere flere af kravene til jurauddannelsen: et højt fagligt niveau samt kompetencer inden for innovation, tværfaglighed og problemløsning. For at imødekomme disse udfordringer er vores projekt inspireret af flere begreber, som bliver opfattet som relevante for god undervis-

\footnotetext{
${ }^{15}$ www.jura.ku.dk/firejournal/innovativ-artikel/idekatalog/.

${ }^{16}$ Jf. bilag 1 til Undervisningsplanen.
} 
ning på universitetsniveau: forskningsbasering og den dermed forbundne dybdelæring, som bliver st $\varnothing$ ttet af formativ feedback; tværfaglighed; innovation og entreprenørskab og den dermed forbundne problemløsningskompetence.

Forskningsbaseret læring skal løfte det akademiske niveau på uddannelsen (Healey \& Jenkins, 2009). Arbejdet med at skrive en akademisk artikel forventes at stimulere dybdelæring (Carter, Ferzli, \& Wiebe, 2007; Klein, Arcon, \& Baker, 2015, s. 252) og ligeså den løbende, formative feedback på teksten (Nicol \& Macfarlane-Dick, 2006) på baggrund af klart kommunikerede kvalitetskriterier (Andrade, 2005; Andrade \& Reddy, 2010; Andrade \& Warner, 2012). Da jura kan betragtes som anvendt videnskab (Becher \& Trowler, 2001, s. 36), er den transdisciplinære gren af tværfaglige forskningstilgange den mest hensigtsmæssige, fordi den fokuserer på løsningen af komplekse samfundsproblemer (Klein, 2010, s. 24-25; Mittelstrass, 2011, s. 331) og socialiserer de studerende til faglig og personlig åbenhed (Armstrong, 1988).

Som studenterpanelet pegede på, vil kurset blive oplevet som stærkt krævende både fagligt og personligt. Derfor har vi udarbejdet meget tydelige rammer for undervisningen. Der er formuleret kriterier for feedback, der er rubrikker for bedømmelse, og der er klar struktur på, hvad der skal foregå på innovationsseminarerne og Innovation Hubs. Vores indsats ligger $\mathrm{i}$ at få disse læringsformer implementeret gennem et anderledes og trygt læringsrum for de studerende med tydelige faglige forventninger og flere former for formativ feedback.

Der findes ikke en underforstået konsensus i det juridiske miljø om, hvad problemorienteret projektarbejde er, og der findes ikke en fælles forståelse af, hvad innovation i forhold til skatteog afgiftsretlige problemer kan være. Der er heller ikke en underforstået konsensus om formative feedbackformer. Derfor har vi udformet meget detaljerede vejledninger, som gerne skulle være til glæde for både studerende og undervisere. I vores iver efter at beskrive og forklare er vi muligvis blevet for detaljerede. Men vi glæder os til at se kursusdesignet folde sig ud, så vi kan revidere det og forhåbentlig videreudvikle forskellige elementer $\mathrm{i}$ andre fag. Det mest spændende bliver naturligvis at se efter gennemf $\varnothing$ relsen af de første kursusforl $\varnothing b$, om vores forventninger baseret på vores kvalificerede antagelser vil kunne indfries, når vi har indhentet evalueringerne af kurset.

Werner Schäfke, ph.d., er adjunkt i juridisk uddannelses- og professionsforskning ved Det Juridiske Fakultet, Københavns Universitet. Han er koordinator for forskningsgruppen for retsvidenskabelig didaktik. Som postdoc i projekterne "Tværfaglig og tværfakultær uddannelse" og "Forskningsbaseret uddannelse" på Københavns Universitet har han forsket om videnskabssociologi af retsvidenskaben og jurauddannelsens funktion inden for den juridiske profession. Han underviser i retsfilosofi og retssociologi på den juridiske bacheloruddannelse og på fakultetets pædagogikum om forskningsbaseret uddannelse.

Bente Kristiansen, ph.d., er læringskonsulent ved Det Juridiske Fakultet, Københavns Universitet, hvor hun arbejder med pædagogikum, holder pædagogiske kurser og workshops og understøtter udviklingsprojekter. Hun har flere års erfaring som skrivekonsulent og er særligt interesseret $i$ akademiske skrive- og læreprocesser. I 2017 udgav hun bogen "Om at skrive på universitetet", Syddansk Universitetsforlag, om betydningen af tekstproduktion i universitetspædagogisk sammenhæng.

Karina Kim Egholm Elgaard, ph.d., er adjunkt ved Det Juridiske Fakultet, Københavns Universitet, samt koordinator for forskningsgruppen FIRE - Fiscal Relations Research Group. Karina forsker i 
moms- og skatteret, og hun skrev sin ph.d.-afhandling om "Interaktionen mellem momsretten og indkomstskatteretten". Hun er i gang med projektet "Combating Tax Avoidance and Protecting the Internal Market - EU VAT Grouping", som er finansieret af Det Frie Forskningsråd. Karina er fagleder og underviser på kurserne "Momsret for virksomheder i EU" og "Innovation og entreprenørskab inden for skatte- og afgiftsret" på kandidatuddannelsen. Hun er projektleder og redaktør for e-tidsskriftet UCPH Fiscal Relations Law Journal.

Maiken Stensgaard Hølmkjær er i 2017 blevet færdiguddannet som cand.jur. fra Det Juridiske Fakultet, Københavns Universitet. I løbet af sin uddannelse har hun fulgt flere af skatte- og afgiftsfagene, og hun har skrevet speciale om "Den momsmæssige behandling af byggegrunde". Derudover har hun været medstifter og formand for det studenterdrevne netværk Young VAT Link. Hun har været projektstudent på dette projekt om opstart af kurset og e-tidsskriftet og fortsætter i redaktionen for UCPH Fiscal Relations Law Journal.

\section{Referencer}

Andrade, H., \& Reddy, Y. M. (2010). A review of rubric use in higher education. Assessment \& Evaluation in Higher Education, 35(4), 435-448.

Andrade, H. G. (2005). Teaching with Rubrics: The Good, the Bad, and the Ugly. College Teaching, 53(1), 27-30.

Andrade, H. L., \& Warner, Z. B. (2012). Beyond "I Give Myself an A". Educator's Voice, 5, 42-51.

Armstrong, F. H. (1988). Reflections on the Nature of Interdisciplinarity: A Reply to Benson, his Critics, and Nicholson. Issues in Interdisciplinary Studies, 6, 152-166.

Becher, T., \& Trowler, P. (2001). Academic tribes and territories: Intellectual enquiry and the culture of disciplines (2nd ed.). Philadelphia, PA: Open University Press.

Carter, M. (2007). Ways of Knowing, Doing, and Writing in the Disciplines. College Composition and Communication, 58(3), 385-418. Retrieved from http://www.jstor.org/stable/20456952.

Carter, M., Ferzli, M., \& Wiebe, E. N. (2007). Writing to Learn by Learning to Write in the Disciplines. Journal of Business and Technical Communication, 21(3), 278-302. https://doi.org/10.1177/1050651907300466.

Det Juridiske Fakultets Aftagerpanel. (2013). Mødereferat: 29. april 2013. København. Retrieved from Det Juridiske Fakultet, Københavns Universitet website: http://jura.ku.dk/om_fakultetet/udvalg/aftagerpanel/referater/.

Det Juridiske Fakultets Aftagerpanel. (2014). Mødereferat: 16. juni 2014. København. Retrieved from Det Juridiske Fakultet, Københavns Universitet website: http://jura.ku.dk/om_fakultetet/udvalg/aftagerpanel/referater/.

Det Juridiske Fakultets Aftagerpanel. (2015). Mødereferat: 20. april 2015. København. Retrieved from Det Juridiske Fakultet, Københavns Universitet website: http://jura.ku.dk/om_fakultetet/udvalg/aftagerpanel/referater/.

Det Juridiske Fakultets Aftagerpanel. (2016a). Mødereferat: 15. marts 2016. København. Retrieved from Det Juridiske Fakultet, Københavns Universitet website: 
http://jura.ku.dk/pdf/formidlingsservice/aftagerpanel/2016/aftagerpanel-referat150316.pdf.

Det Juridiske Fakultets Aftagerpanel. (2016b). Mødereferat: 4. oktober 2016. København. Retrieved from Det Juridiske Fakultet, Københavns Universitet website: http://jura.ku.dk/pdf/formidlingsservice/aftagerpanel/2016/aftagerpanel-referat041016.pdf.

Det Juridiske Fakultets Aftagerpanel. (2017). Mødereferat: 2. maj 2017. København. Retrieved from Det Juridiske Fakultet, Københavns Universitet website: http://jura.ku.dk/pdf/201705-02_Referat_af_m_de_den_2._maj.pdf.

Fuller, L. L. (1950). On Teaching Law. Stanford Law Review, 3(1), 35-47.

Hammerslev, O. (2010). Empiriske undersøgelser af den juridiske profession i nationale og transnationale kontekster. In A. Storgaard \& B. Lemann Kristiansen (Eds.), Nordisk Retssociologi. Status - aktuelle udfordringer - visioner (s. 161-173). DJØF.

Hammerslev, O. (2011). At studere juridiske eliter. In H. V. Godsk Pedersen (Ed.), Juridiske emner ved Syddansk Universitet (s. 44-54). DJØF.

Hattie, J., \& Timperley, H. (2007). The Power of Feedback. Review of Educational Research, 77(1), 81-112. https://doi.org/10.3102/003465430298487.

Healey, M., \& Jenkins, A. (2009). Developing undergraduate research and inquiry. York: Higher Education Academy.

Jørgensen, S., Dolin, J., Hvithamar, A., Magnusson, F. L., \& Holde, S. G. (2015). Feedback på KU. København.

Klein, J. T. (2010). A Taxonomy of Interdisciplinarity. In R. Frodeman, J. T. Klein, \& C. Mitcham (Eds.), The Oxford handbook of interdisciplinarity (s. 15-30). Oxford, New York: Oxford University Press.

Klein, P. D., Arcon, N., \& Baker, S. (2015). Writing to Learn. In C. A. MacArthur, S. Graham, \& J. Fitzgerald (Eds.), Handbook of writing research (s. 243-256). New York: The Guilford Press.

Krogh, L., Stentoft, D., Emmersen, J., \& Mausaeus, P. (2013). Casebaseret undervisning. In L. Rienecker, P. S. Jørgensen, J. Dolin, \& G. H. Ingerslev (Eds.), Universitetspædagogik (s. 201214). Frederiksberg: Samfundslitteratur.

Københavns Universitet. (2013). Læringsmål for innovation og entrepren $\varnothing r s k a b$. Retrieved from https://innovation.sites.ku.dk/files/2016/11/IE-laeringsmaal_VK.pdf.

Københavns Universitet. (2016). Studiemiljøundersøgelse 2016: Jura. Udannelsesrapport. København.

Madsen, M. R. (2008). Return to the Copenhagen Magic Circle: First Elements of Longitudinal Study of Large Law Firms in Denmark. Scandinavian Studies in Law, 53, 303-319.

Mittelstrass, J. (2011). On Transdisciplinarity. Trames, 15(4), 329-338.

Murray, R. (2012). Social writing. In L. Clughen \& C. Hardy (Eds.), Writing in the disciplines. Building supportive cultures for student writing in UK higher education (s. 187-210). Bingley: Emerald. 
Nicol, D., Thomson, A., \& Breslin, C. (2013). Rethinking feedback practices in higher education: A peer review perspective. Assessment \& Evaluation in Higher Education, 39(1), 102-122. https://doi.org/10.1080/02602938.2013.795518.

Nicol, D. J., \& Macfarlane-Dick, D. (2006). Formative assessment and self-regulated learning: A model and seven principles of good feedback practice. Studies in Higher Education, 31(2), 199-218. https://doi.org/10.1080/03075070600572090.

Pedersen, K. (2015). Problemorienteret projektarbejde. In P. B. Olsen \& K. Pedersen (Eds.), Problemorienteret projektarbejde (4th ed., s. 13-25). Frederiksberg: Samfundslitteratur.

Tynjälä, P. (1998). Writing as a Tool for Constructive Learning: Students' Learning Experiences during an Experiment. Higher Education, 36(2), 209-230. Retrieved from http://www.jstor.org/stable/3448161.

Wilhelmsen, L. S. (2014a). Fordord. In L. S. Wilhelmsen (Ed.), Juridisk fagdidaktikk. Med vekt på studentenes læring (s. 5-6). Bergen: Fagbokforlaget.

Wilhelmsen, L. S. (Ed.). (2014b). Juridisk fagdidaktikk: Med vekt på studentenes læring. Bergen: Fagbokforlaget.

Wilhelmsen, L. S. (2014c). Utforming av oppgaver. In L. S. Wilhelmsen (Ed.), Juridisk fagdidaktikk. Med vekt på studentenes læring (s. 153-170). Bergen: Fagbokforlaget.

Zyngier, D. (2014). Class size and academic results, with a focus on children from culturally, linguistically and economically disenfranchised communities. Evidence Base, 2014(1), 1-24. https://doi.org/10.4225/50/5582118F8790B.

Education Research \& Development, 33(3), 610-626. 